\title{
Modulation of gene expression in cholesterol-lowering effect of electroacupuncture at Fenglong acupoint (ST40): A cDNA microarray study
}

\author{
MIN LI and YIZHENG ZHANG \\ Sichuan Key Lab of Molecular Biology and Biotechnology, College of Life Science, \\ Sichuan University, Chengdu 610064, P.R. China
}

Received September 12, 2006; Accepted November 14, 2006

\begin{abstract}
The aim of this study was to demonstrate the cholesterol-lowering effect of electroacupuncture (EA) at the acupoint of Fenglong (ST40) in mice and to investigate its molecular mechanism by using genome-wide gene expression profile analysis. Mice with hypercholesterolemia induced by a high-cholesterol diet were randomly divided into EA at ST40 group (EG), EA at non-acupoint group (ENG), and simvastatin group (DG). A lipid profile of both the plasma and liver indicated that EA at ST40 had the same hypocholesterolemic effect as that of simvastatin, while EA at non-acupoint failed to produce the same effect. The global gene expression profile showed that EA at ST40 not only regulated the expression of genes which were directly involved in the cholesterol metabolism in the liver, but also significantly affected the expression of genes involved in signal transduction, transcription regulation, cell cycle, cell adhesion, immunity and stress. The gene expression pattern was further verified by real-time RT-PCR. The mechanism by which EA at ST40 regulated liver cholesterol metabolism is discussed. We conclude that the hypocholesterolemic effect is specific to EA at ST40 and not due to general electrical stimulation of muscles. The comprehensive gene expression profile analysis appears particularly useful in the search for EA-induced changes in cholesterol regulation.
\end{abstract}

\section{Introduction}

Hypercholesterolemia is a major risk factor for coronary heart disease, which is one of the leading causes of death in both men and women (1). Drugs used to treat hypercholesterolemia include statins, bile acid sequestrants, fibric acids, and nicotinic acid (2). Among these cholesterol-lowering drugs, statins are the safest and most effective. Although adverse effects of statins are generally mild and transient, more serious adverse

Correspondence to: Dr Yizheng Zhang, College of Life Science, Sichuan University, Chengdu 610064, P.R. China

E-mail: yizzhang@scu.edu.cn

Key words: electroacupuncture, gene expression, hypercholesterolemia, cDNA microarray effects, including myotoxicity, liver toxicity, and rhabdomyolysis, are still possible with statin monotherapy and are more common in patients receiving concomitant therapy with other drugs metabolized by the cytochrome P450 pathway (3).

Alternative therapies have received wide attention recently (4). Among these, acupuncture therapy has more than two thousand years of history in Traditional Chinese Medicine. Acupuncture and electroacupunture (EA) have been applied with great success to regulate blood lipids in patients with lipid metabolism disorders (5-8). For instance, acupuncture at ST40 significantly reduces the serum total cholesterol (TC) and low-density lipoprotein cholesterol (LDL-c) levels in patients with hypercholesterolemia (9). Moreover, the success of acupuncture on treating hyperlipemia has also been verified by animal experiments. Acupuncture at ST40 could markedly decrease the levels of TC, LDL-c and total triglycerides (TG) in the rat model of hyperlipemia $(10,11)$. The State Administration of Traditional Chinese Medicine of People's Republic of China is compiling an encyclopedia of acupoints with proven functions (http://www.satcm.gov.cn/). The treatment of hypercholesterolemia by acupuncture at ST40 has been ingathered in the encyclopedia. However, the molecular mechanism by which EA at ST40 exerts hypocholesterolemic effects remains unclear.

The aim of this study was to investigate potential molecular mechanism of the hypocholesterolemic effects by EA at ST40 by establishing a mouse model of hypercholesterolemia and utilizing high-density cDNA microarrays for genome-wide gene expression profile analysis. cDNA microarray studies have been used in researching the retardation effect of EA on aging in senescence-accelerated mice (12) and the protective effects of EA against cerebral ischemia in monkeys (13). We compared the hypocholesterolemic effect of EA at ST40 with those of EA at non-acupoint and simvastatin treatment by plasma lipid profile and cDNA microarray analysis. We present evidence suggesting that EA at ST40 exerts hypocholesterolemic effects through distinct molecular mechanisms.

\section{Materials and methods}

Experiment design. An overview of the experiment design is provided in Fig. 1. 


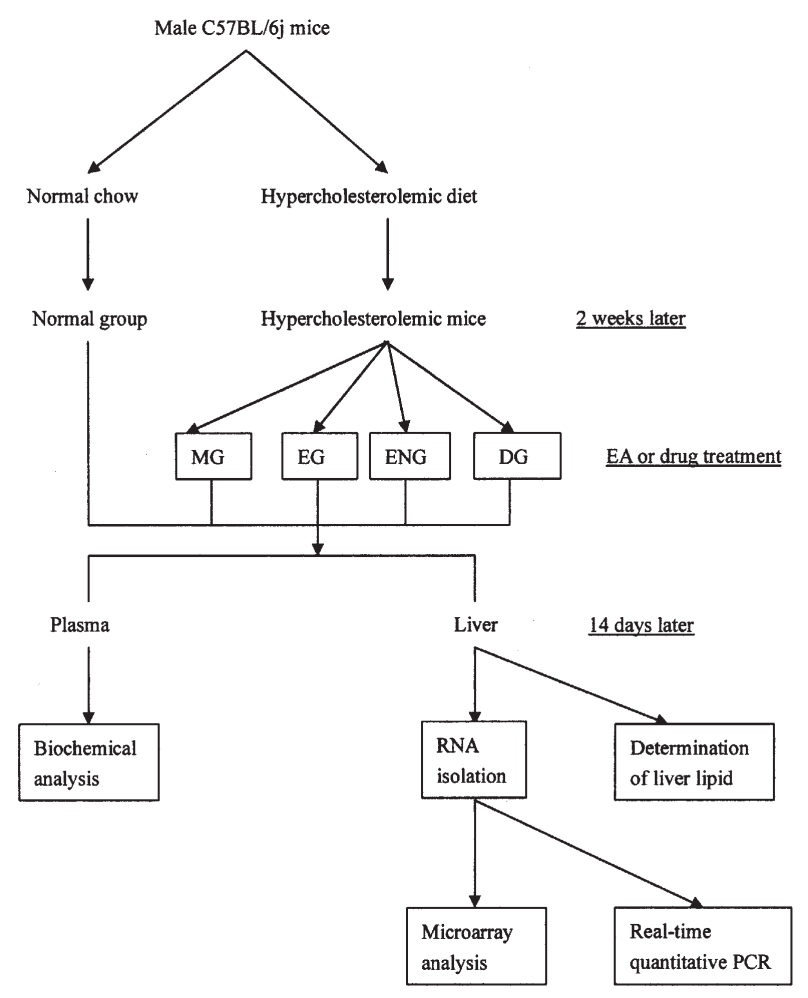

Figure 1. An overview of the experiment design. Male C57BL/6j mice were divided randomly into two groups: a normal group (NG), and a hypercholesterolemic diet group (HDG). NG $(n=9)$ were fed with standard laboratory chow and HDG $(n=36)$ were fed a hypercholesterolemic diet (HD) containing $75 \%$ chow, $10 \%$ coca butter, $2 \%$ cholesterol, and $0.2 \%$ deoxycholic acid sodium salt. Plasma cholesterol and triglyceride levels were determined after 2 weeks in NG and HDG mice. Mice in the HDG with higher plasma cholesterol were assigned as hypercholesterolemia mice $(n=36)$. These hypercholesterolemia mice were then divided randomly into the following four groups ( $\mathrm{n}=9$ for each group): EA at ST40 group (EG), EA at non-acupoint group (ENG), drug group (DG) serving as the positive control and model group (MG) which received no further treatment serving as the negative control. These four groups were fed HD continuously. The mice of DG were given i.g. $0.3 \mathrm{~g} / 1$ simvastatin $0.2 \mathrm{ml}$ once a day. The mice of EG started EA treatment at ST40, whereas the mice of ENG started EA at non-acupoint in the meantime. EA treatment lasted 20 min per session and was performed at 8:00-9:00 am. For EG and ENG mice, EA treatment started on the 16th day and lasted 2 weeks. EA was performed daily except the $18 \mathrm{th}, 22 \mathrm{nd}, 26 \mathrm{th}$, and 27 th day. At the end of the 30-day experimental duration, the mice were fasted overnight and sacrificed. Blood was obtained for biochemical analysis. Livers were quickly excised and dissected for different purposes. Parts of the right leaflets of liver tissues were stored at $-20^{\circ} \mathrm{C}$ for later lipid extraction. The left leaflets of liver tissue were soaked in RNA Later for total RNA isolation. Microarray analysis and real-time quantitative PCR were then performed.

Animal treatment. Male C57BL/6j mice, aged 13 weeks and weighing about $29 \mathrm{~g}$, were obtained from the Shanghai Laboratory Animal Center, Chinese Academy of Sciences, P.R. China. These mice were maintained in the experimental animal center of Chengdu University of Traditional Chinese Medicine. They were housed collectively (four per cage) in an air-conditioned room $\left(22 \pm 2^{\circ} \mathrm{C}\right)$ with a 12 -h light/dark cycle and with free access to food and water. All animal treatments were performed in accordance with institutional guidelines from the Animal Care Committee of the Chengdu University of Traditional Chinese Medicine.

After 1 week of adaptation, 9 mice were randomly selected for sacrifice under isoflurane anesthesia. Blood plasma was obtained by retroorbital bleeding into heparinized tubes and biochemical analyses were carried out using an automated enzymatic assay (Hitachi 7170A automatic analyzer, Japan), including measurements for plasma total-, LDL-, and high density lipoprotein (HDL)-cholesterol; TG; total protein (TP); album (ALB); globin (GLOB); album/globin (A/G); glucose; creatinine (Crea); nitrogen urea (Bun); aspartate aminotransferase (AST); and alanine aminotransferase (ALT).

The other mice were divided randomly into two groups: a normal group and a hypercholesterolemic diet (HD) group. The normal group $(\mathrm{n}=9)$ were fed ad libitum with standard laboratory chow. The HD group $(\mathrm{n}=36)$ were fed ad libitum a hypercholesterolemic diet (HD) containing 75\% chow, 10\% coca butter, 2\% cholesterol (Amresco, lot: 2551A82 CAS 5788-5), and $0.2 \%$ deoxycholic acid sodium salt (Amresco, lot: 0613). Blood was obtained from mice who fasted for $16 \mathrm{~h}$ by retroorbital bleeding under isoflurane anesthesia after 2 weeks. Plasma cholesterol and triglyceride levels were determined using an automated enzymatic assay as described above. Mice in the HD group with higher plasma cholesterol were assigned as hypercholesterolemia mice $(n=36)$. Their average plasma total cholesterol was $6.87 \pm 0.36 \mathrm{mM}, 2.37$ times that of the normal group $(2.89 \pm 0.27 \mathrm{mM})$. The hypercholesterolemia mice were then divided randomly into the following four groups ( $n=9$ for each group): EA at ST40 group (EG), EA at non-acupoint group (ENG), drug group (DG) serving as the positive control and model group (MG) which received no further treatment serving as the negative control. These four groups were fed HD continuously. The mice of DG were given i.g. $0.3 \mathrm{~g} / 1$ simvastatin $0.2 \mathrm{ml}$ (Merck \& Co., Inc., Whitehouse Station, NJ, USA) once a day. The mice of EG started EA treatment at ST40, whereas the mice of ENG started EA at non-acupoint in the meantime.

The acupoint of Fenglong. One unit in acupuncture is defined as $1 / 14$ of the distance between the top of the xiphoid process and the upper crest of pubis bond (14). According to the Atlas of Animal Points made by the Institute of Experimental Acupuncture Research of China, the Fenglong acupoint is on the outside of crus, 8 units above the outer top of the ankle and 1 unit apart from the front of the cannon bone. Another two points were also stimulated as non-acupoint control: each point was inserted in parallel at 2 units beside the peak in the buttock, respectively.

Electroacupuncture (EA). A sterile acupuncture needle of 0.5 inches in length (Suzhou medical instruments factory, Suzhou, P.R. China) was inserted into the muscle layer at the selected acupoint to a depth of $2 \mathrm{~mm}$. The left Fenglong acupoint was connected to the positive charge and the right one to the negative charge of a pulse generator (G6805-2, Shanghai Medical Electronic Apparatus Company, P.R. China) which emits dense-sparse waves (dense wave: $18 \mathrm{~Hz}$, $0.5 \mathrm{~mA}$, duration time $1.05 \mathrm{sec}$; sparse wave: $3.85 \mathrm{~Hz}, 0.5 \mathrm{~mA}$, duration time $2.85 \mathrm{sec}$ ). EA treatment lasted $20 \mathrm{~min}$ per session and was performed at 8:00-9:00 am. For EG and ENG mice, EA treatment started on the 16th day and lasted 2 weeks. EA was performed daily except the 18th, 22nd, 26th, and 27th day. The purpose of having a rest on these days was to avoid stimulation tolerances. 
At the end of the 30-day experimental duration, the mice were fasted overnight and sacrificed after blood was obtained by retroorbital bleeding under isoflurane anesthesia. Livers were quickly excised and dissected for different purposes. Parts of the right leaflets of liver tissue were stored at $-20^{\circ} \mathrm{C}$ for later lipid extraction. The left leaflets of liver tissue were soaked in RNA Later (Ambion, Austin, TX, USA) for total RNA isolation.

Lipid analysis in liver. Total lipids from the livers were extracted and purified according to Folch et al (15). The total cholesterol and total triglyceride in the liver were determined as clinic samples by an automated enzymatic assay as described above.

Statistical analyses. All concentration was given as mean \pm SEM. Group comparisons were made by analysis of variance (ANOVA) and the Student-Newman-Keuls test. p-values $<0.05$ were considered statistically significant.

RNA extraction. RNA was extracted with Trizol reagent (Invitrogen, Gaithersburg, MD, USA) and further purified with an RNeasy mini kit (Qiagen, Valencia, CA, USA) according to the manufacturer's instructions. The RNA quality was assessed by formaldehyde agarose gel electrophoresis and quantitated spectrophotometrically. The mRNA sample for chip hybridization was prepared by mixing the mRNA samples of every mouse from the same group in equal quantities.

Construction of mouse genome oligonucleotide microarray. The mouse genome oligonuleotide microarray was constructed at Capitalbiochip Corporation (Beijing, P.R. China). In brief, a Mouse Genome Oligo Set Version 2.0 consisting of 5'amino-modified 70-mer probes representing 16,463 wellcharacterized $M$. musculus genes were purchased from Qiagen (http://oligos.qiagen.com/arrays/oligosets_overview. php). In addition to internal controls provided by the manufacturer, three 70-mers representing Arabidopsis genes were added as external controls. All nucleotides were dissolved in 50\% DMSO to a final concentration of $40 \mu \mathrm{M}$ and printed on amino silaned glass slides. Arrays were fabricated by using an OmniGrid ${ }^{\mathrm{TM}}$ microarrayer (Genomic Instrumentation Services, Inc, San Carlos, CA, USA). After printing, the slides were baked for $1 \mathrm{~h}$ at $80^{\circ} \mathrm{C}$ and stored dry at room temperature till use.

Prior to hybridization, the slides were rehydrated in $65^{\circ} \mathrm{C}$ water for $10 \mathrm{sec}$, snap dried on a $100^{\circ} \mathrm{C}$ heating block for $5 \mathrm{sec}$ and UV cross-linked at $250 \mathrm{~mJ} / \mathrm{cm}^{2}$. The unimmobilized oligonucleotides were washed off with $0.5 \%$ SDS for $15 \mathrm{~min}$ at RT and SDS was removed by dipping the slides in anhydrous ethanol for $30 \mathrm{sec}$. The slides were spin-dried at $1000 \mathrm{rpm}$ for $2 \mathrm{~min}$.

Preparation of fluorescent dye-labeled DNA and hybridization. Fluorescent dye (cy5 and cy3-dCTP)-labeled DNA was produced through single primer amplification (SPA) reaction (16). Briefly, double-stranded cDNA was synthesized using a template of $2 \mu \mathrm{g}$ total RNA and a cDNA synthesis system kit according to the manufacturer's recommended protocol (Takara, Dalian, P.R. China). A modified oligonucleotide (5'-
CTC TCA AGG ATC TTA CCG CTT TTT TTT TTT TTT TTTV-3') was used in place of a poly-T primer provided in the kit (17).

After completion of cDNA synthesis, double-stranded cDNA was purified with a PCR purification kit (Qiagen), and the final cDNA was eluted in a $60 \mu 1$ elution buffer. SPA was performed with $15 \mu \mathrm{l}$ of the eluted DNA as a template and a heel primer (5'-CTC TCA AGG ATC TTA CCGC-3'), and subsequently purified as described earlier and resuspended in $20 \mu 1 \mathrm{H}_{2} \mathrm{O}$. SPA products were labeled with the Klenow labeling kit (Takara) according to a published protocol. Briefly, the above $10 \mu \mathrm{l}$ SPA product was mixed with $2 \mu \mathrm{g}$ random nonamer oligonucleotides. The template and primer solution were heated to $95^{\circ} \mathrm{C}$ for $3 \mathrm{~min}$ and snap-cooled on ice. dNTP and Cy5-dCTP or Cy3-dCTP (Amersham Pharmacia Biotech, Inc., Piscataway, NJ, USA) were added at a final concentration of $120 \mu \mathrm{M}$ each of dATP, dGTP, dTTP; $60 \mu \mathrm{M}$ of dCTP; and $40 \mu \mathrm{M}$ Cy-dye, respectively. The labeled DNA was purified with a PCR purification kit (Qiagen), resuspended in $\mathrm{H}_{2} \mathrm{O}$ and checked O.D. Labeled control and test samples were normalized based on the efficiency of the Cy-dye incorporation and mixed into $30 \mu 1$ hybridization solution (3X SSC, $0.2 \%$ SDS, $25 \%$ formamide and 5X Denhart's). DNA in hybridization solution was denatured at $95^{\circ} \mathrm{C}$ for 3 min prior to loading on a microarray chip. The chip was hybridized at $42^{\circ} \mathrm{C}$ overnight and washed sequentially with two washing solutions $(0.2 \%$ SDS, $2 \mathrm{X} \mathrm{SSC}$ at $42^{\circ} \mathrm{C}$ for $5 \mathrm{~min}$, and $0.2 \% \mathrm{SSC}$ for $5 \mathrm{~min}$ at room temperature).

Imaging and data analysis. Arrays were scanned with a ScanArray Express scanner (Packard Bioscience, Kanata, OT, USA), and obtained images were analyzed with GenePix Pro 4.0 (Axon Instruments, Foster City, CA, USA). A space and intensity-dependent normalization based on the Lowess program (18) was employed here.

The fluorescent dye reversals were performed to prevent confounding of fluorescent dye biases. The hybridization combinations were MG versus NG, MG versus EG, MG versus ENG, and MG versus DG. Spots whose ratio lay outside the 95\% confidence interval were determined as significant differentially expressed genes. The significant differentially expressed genes were grouped into categories according to the Gene Ontology Consortium (http://www.geneontology.org/).

Real-time quantitative RT-PCR. Total RNA was treated with DNase I to eliminate the traces of genomic DNA. Total RNA $(2 \mu \mathrm{g})$ was employed to synthesize the first strand of cDNA in a $20 \mu 1$ reverse transcription (RT) reaction, and $2 \mu 1$ of $\mathrm{RT}$ product were used in PCR amplification using the LightCycle PCRs system (Roche Molecular Biochemicals, Mannheim, Germany) and the SYBR-Green I monitoring method. The relative expression ratio $(\mathrm{R})$ of a target gene was calculated based on amplification efficiencies (E) and the crossing point (CP) deviation of an unknown sample versus a control, and expressed in comparison to a reference gene (19):

$$
\text { Ratio }=\frac{\left(E_{\text {target }}\right) \Delta \mathrm{CP}_{\text {target }}(\text { control-sample })}{\left(E_{\text {ref }}\right) \Delta \mathrm{CPref} \text { (control-sample) }}
$$

The MG RNA was used as control. The EG, NG and DG RNA was used as sample, respectively. The glyceraldehyde- 
Table I. The biochemical analysis result of blood at the beginning of the experiment $(n=9)$.

\begin{tabular}{|c|c|c|c|c|c|c|c|c|c|c|c|}
\hline $\begin{array}{l}\text { Bun } \\
(\mathrm{mM})\end{array}$ & $\begin{array}{l}\text { Crea } \\
(\mu \mathrm{M})\end{array}$ & $\begin{array}{l}\mathrm{TP} \\
(\mathrm{g} / \mathrm{l})\end{array}$ & $\begin{array}{l}\text { ALB } \\
(\mathrm{g} / 1)\end{array}$ & $\begin{array}{c}\text { GLOB } \\
(\mathrm{g} / \mathrm{l})\end{array}$ & $\mathrm{A} / \mathrm{G}$ & $\begin{array}{l}\text { ALT } \\
(\mathrm{IU} / \mathrm{l})\end{array}$ & $\begin{array}{l}\text { AST } \\
(\mathrm{IU} / 1)\end{array}$ & $\begin{array}{c}\mathrm{TG} \\
(\mathrm{mM})\end{array}$ & $\begin{array}{c}\mathrm{TC} \\
(\mathrm{mM})\end{array}$ & $\begin{array}{l}\text { HDL-c } \\
(\mathrm{mM})\end{array}$ & $\begin{array}{l}\text { LDL-c } \\
(\mathrm{mM})\end{array}$ \\
\hline $7.67 \pm 1.21$ & $33.98 \pm 4.23$ & $60.7 \pm 3.58$ & $33.22 \pm 1.50$ & $25.2 \pm 2.41$ & $1.22 \pm 0.01$ & $37.88 \pm 13.04$ & $142.11 \pm 27.80$ & $0.70 \pm 0.10$ & $2.68 \pm 0.34$ & $0.68 \pm 0.11$ & $1.64 \pm 0.21$ \\
\hline
\end{tabular}

Table II. The plasma total cholesterol and total triglyceride level in normal group and HD mice after two weeks.

\begin{tabular}{lcc}
\hline & Normal mice $(\mathrm{n}=9)$ & HD mice $(\mathrm{n}=36)$ \\
\hline Total cholesterol $(\mathrm{mM})$ & $2.89 \pm 0.27^{\mathrm{a}}$ & $6.87 \pm 0.36$ \\
Total triglyceride $(\mathrm{mM})$ & $0.76 \pm 0.14$ & $0.83 \pm 0.09$ \\
\hline${ }^{\mathrm{a}} \mathrm{p}<0.01$ vs HD mice. & & \\
\hline
\end{tabular}

3-phosphate dehydrogenase (GAPDH) gene was used as a reference gene after a pilot comparison between several housekeeping genes. The amplification efficiencies (E) of different target genes were calculated independently according to a statistic delimitation of the beginning of exponentially behaving observation in real-time PCR kinetics instead of utilizing 2 as a fixed amplification efficiency (20). The target genes included two genes which were detected as differentially expressed genes in all microarray results: secretary leukocyte protease inhibitor (Slpi) and growth differentiation factor 15 (Gdf15); and the genes which were associated with the cholesterol metabolism in liver including liver $\mathrm{X}$ receptor $\alpha(\mathrm{LXR} \alpha)$, farnesoid $\mathrm{X}$ receptor $(\mathrm{FXR})$, peroxisome proliferator activator $\alpha(\mathrm{PPAR} \alpha)$, cholesterol $7 \alpha$ hydroxlase (CYP7A1), HMG-CoA reductase (Hmgcr), sodium taurocholate cotransporting polypeptide (NTCP), organic anion transporting protein 1 (OATP-1), canalicular bile salt export pump (BSEP), scavenger receptor B1 (Scarb1), and LDL receptor (LDLR). The primer sequences of genes for real-time quantitative RT-PCR were as follows: LXR $\alpha$ sense, 5'-CCC ACG GAT GCT AAT GAA G-3'; LXR $\alpha$ antisense, 5'-CAC AAA GGA CAC GGT GAA AC-3'; FXR-sense, 5'-GAG ATG CTG ATG TCT TGG A-3'; FXR-antisense, 5'-ACA ACC GTG GGA GGT GTA T-3'; PPAR $\alpha$-sense, 5 '-AGT CCC TTT TCC TCA GTC C-3'; PPAR $\alpha$-antisense, 5'-TTT TCT AAA GAT GGG TCG G-3'; CYP7A1-sense, 5'-GTT GTC TCC TGC GAC TTC A-3'; CYP7A1-antisense, 5'-TGG TCC AGG GTT TCT TAC TC3'; Hmgcr-sense, 5'-GGG ACC AAC CTT CTA CCT C-3'; Hmgcr-antisense, 5'-AAG ATG TCC TGC TGC CAA G-3'; NTCP-sense, 5'-GGA AGC CCA AAG GGG TGA T-3'; NTCP-antisense, 5'-CAG GGT GAA GAG GTT AGA C-3'; OATP-1-sense, 5'-ACA TTT ACC TGG GGT TGC C-3'; OATP-1-antisense, 5'-CTC GAC CTT AGG ACT TCT GC-3'; BSTP-sense, 5'-TTC TGA ATG GAC TGT CGG TAT-3'; BSTP-antisense, 5'-CCC AAT GTT TGA ACG GAG G-3'; Scarb1-sense, 5'-TGG ACA AAT GGA ACG GAC T-3'; Scarb1-antisense, 5'-GGA ATG CCT TCA AAC ACC C-3';
LDLR-sense, 5'-CCC ACG GAT GCT AAT GAA G-3'; LDLR-antisense, 5'-CAC AAA GGA CAC GGT GAA AC-3'; GAPDH-sense, 5'-GTT GTC TCC TGC GAC TTC A-3'; and GAPDH-antisense, 5'-TGG TCC AGG GTT TCT TAC TC-3'.

\section{Results and discussion}

Effect of EA on plasma cholesterol levels. The level of plasma total cholesterol at the beginning of the experiment was $2.68 \pm 0.34 \mathrm{mM}(\mathrm{n}=9)$. Other plasma biochemical analyses suggested that the mice were healthy (Table I). Two weeks after they were fed with the high cholesterol diet, the plasma total cholesterol levels in HD mice were markedly raised to $6.87 \pm 0.36 \mathrm{mM}$ ( $\mathrm{n}=36, \mathrm{p}<0.01$ compared with normal group), as shown in Table II. Thus, according to the guideline (21), the hypercholesterolemia mouse model was successfully constructed.

Table III lists the results of plasma biochemical analysis in all five groups of mice after the 16-day treatment. Remarkably, the levels of plasma total-, LDL-, and HDLcholesterol were significantly different among these five groups, while the total triglyceride level could not be statistically compared among these groups because of different variance. In contrast, the other biochemical parameters were not significantly different among these groups. The results indicated that EA or simvastatin specifically influenced the plasma lipid profile, and did not influence the normal liver and kidney function of the mice.

The increase in the plasma total-, LDL-, and HDLcholesterol levels in the MG mice were significant $(\mathrm{p}<0.01)$ compared with those in the NG mice $(9.44 \pm 0.80 \mathrm{mM}$ vs $2.77 \pm 0.44 \mathrm{mM} ; 2.36 \pm 0.20 \mathrm{mM}$ vs $0.69 \pm 0.15 \mathrm{mM}$; and $6.87 \pm 0.74 \mathrm{mM}$ vs $1.91 \pm 0.37 \mathrm{mM}$, respectively).

After the treatment, the levels of plasma total-, LDL-, and HDL-cholesterol were significantly reduced $(\mathrm{p}<0.01)$ in the EG mice compared with corresponding values in the $\mathrm{MG}$ mice $(5.96 \pm 0.53 \mathrm{mM}$ vs $9.44 \pm 0.80 \mathrm{mM} ; 1.61 \pm 0.26 \mathrm{mM}$ vs $2.36 \pm 0.20 \mathrm{mM}$; and $4.56 \pm 0.22 \mathrm{mM}$ vs $6.87 \pm 0.74 \mathrm{mM}$, respectively). Similarly, the levels of plasma TC, HDL-c, LDL$\mathrm{c}$ in the DG mice were also significantly lowered $(\mathrm{p}<0.01)$ (Fig. 2) compared with those in the MG mice (5.53 \pm 0.55 vs $9.44 \pm 0.80 ; 1.37 \pm 0.14$ vs $2.36 \pm 0.20$; and $4.19 \pm 0.55$ vs $6.87 \pm 0.74$, respectively). In conclusion, our results indicated that the hypercholesterolemic effect of EA stimulation at ST40 was similar to that of simvastatin.

The specific effect of EA stimulation at ST40 was contrasted by the lack of effect by similar EA stimulation at non-acupoint locations. As shown in Fig. 3, the plasma total-, LDL-, and HDL-cholesterol concentrations in mice receiving EA stimulation at the non-acupoint did not change significantly when compared with corresponding values in the MG mice 
Table III. The biochemical analysis result of blood in NG, MG, EG, ENG and DG after 16-day treatment.

\begin{tabular}{|c|c|c|c|c|c|}
\hline & $\mathrm{NG}(\mathrm{n}=8)$ & MG $(n=8)$ & ENG $(n=9)$ & EG $(n=8)$ & DG $(n=8)$ \\
\hline Bun & $8.26 \pm 1.20$ & $8.88 \pm 1.40$ & $7.90 \pm 1.09$ & $7.40 \pm 1.43$ & $8.79 \pm 1.91$ \\
\hline Crea & $31.07 \pm 3.06$ & $35.13 \pm 3.17$ & $35.82 \pm 3.90$ & $34.58 \pm 4.33$ & $36 \pm 2.60$ \\
\hline TP & $60.66 \pm 4.58$ & $61.88 \pm 8.29$ & $62.74 \pm 4.86$ & $60.01 \pm 7.56$ & $61.35 \pm 3.63$ \\
\hline ALB & $33.18 \pm 1.43$ & $32.85 \pm 1.93$ & $33.64 \pm 1.48$ & $32.35 \pm 2.82$ & $33.17 \pm 1.52$ \\
\hline GLOB & $27.47 \pm 3.46$ & $29.03 \pm 6.50$ & $29.1 \pm 3.84$ & $27.66 \pm 5.08$ & $28.17 \pm 2.67$ \\
\hline $\mathrm{A} / \mathrm{G}$ & $1.21 \pm 0.11$ & $1.16 \pm 0.18$ & $1.17 \pm 0.13$ & $1.18 \pm 0.14$ & $1.18 \pm 0.11$ \\
\hline ALT & $26.5 \pm 10.07$ & $31.37 \pm 2.32$ & $30.77 \pm 7.74$ & $32.87 \pm 5.86$ & $27.25 \pm 5.12$ \\
\hline AST & $143.75 \pm 25.52$ & $158.37 \pm 17.32$ & $158.33 \pm 22.69$ & $154.87 \pm 31.18$ & $142.87 \pm 18.54$ \\
\hline TG & $0.83 \pm 0.12$ & $0.74 \pm 0.15$ & $0.77 \pm 0.09$ & $0.85 \pm 0.18$ & $0.72 \pm 0.08$ \\
\hline $\mathrm{TC}$ & $\begin{array}{l}2.77 \pm 0.44 \\
\text { aaccddee }\end{array}$ & $\begin{array}{c}9.44 \pm 0.80 \\
\text { bbccdd }\end{array}$ & $\begin{array}{c}9.50 \pm 0.53 \\
\text { bbccdd }\end{array}$ & $\begin{array}{c}5.96 \pm 0.53 \\
\text { aabbee }\end{array}$ & $\begin{array}{c}5.53 \pm 0.55 \\
\text { aabbee }\end{array}$ \\
\hline HDL-c & $\begin{array}{l}0.69 \pm 0.15 \\
\text { aaccddee }\end{array}$ & $\begin{array}{c}2.36 \pm 0.20 \\
\text { bbccdd }\end{array}$ & $\begin{array}{c}2.15 \pm 0.37 \\
\text { bbccdd }\end{array}$ & $\begin{array}{l}1.61 \pm 0.26 \\
\text { aabbee }\end{array}$ & $\begin{array}{l}1.37 \pm 0.14 \\
\text { aabbee }\end{array}$ \\
\hline LDL-c & $\begin{array}{l}1.91 \pm 0.37 \\
\text { aaccddee }\end{array}$ & $\begin{array}{l}6.87 \pm 0.74 \\
\text { bbccdd }\end{array}$ & $\begin{array}{c}7.13 \pm 0.30 \\
\text { bbccdd }\end{array}$ & $\begin{array}{c}4.56 \pm 0.22 \\
\text { aabbee }\end{array}$ & $\begin{array}{c}4.19 \pm 0.55 \\
\text { aabbee }\end{array}$ \\
\hline
\end{tabular}

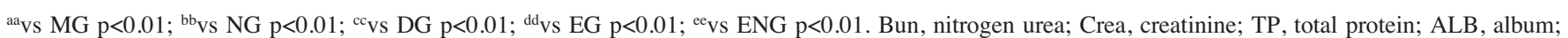
GLOB, globin; A/G, album/globin; ALT, alanine aminotransferase; AST, aspartate aminotransferase; TG, total triglyceride; TC, total cholesterol; HDL-c, high-density lipoprotein cholesterol; LDL-c, low-density lipoprotein cholesterol.

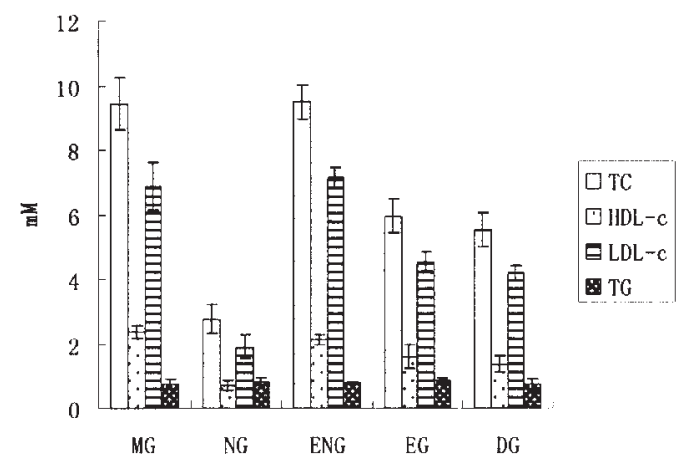

Figure 2. The biochemical analysis result of blood in NG, EG, ENG and DG at the end of the experiment. Vertical bars represent mean \pm SEM of 8-9 mice. TC, total cholesterol; TG, total triglyceride; LDL-c, low-density lipoprotein cholesterol; HDL-c, high-density lipoprotein cholesterol.

(see Table III to compare the ENG group with the MG group). Therefore, the hypocholesterolmic effect is specific to EA at ST40 and not due to general electrical stimulation of muscles.

Effect of EA on liver lipid. Similar to its effect on plasma, the high cholesterol diet also changed the lipid profile in liver. As shown in Table IV and Fig. 3, the levels of the hepatic total cholesterol and total triglyceride in the MG mice increased

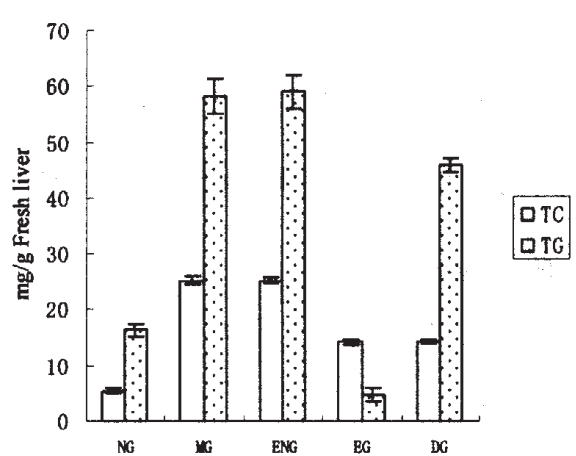

Figure 3. The content of total cholesterol and total triglyceride in fresh liver in MG, NG, EG, ENG and DG at the end of the experiment. Vertical bars represent mean \pm SEM of 8-9 mice. TC, total cholesterol in fresh liver; TG, total triglyceride in fresh liver.

significantly $(\mathrm{p}<0.01)$ when compared with corresponding values in the NG mice $(25.15 \pm 0.76 \mathrm{mg} / \mathrm{g}$ vs $5.41 \pm 0.40 \mathrm{mg} / \mathrm{g}$; and $58.23 \pm 3.02 \mathrm{mg} / \mathrm{g}$ vs $16.37 \pm 1.12 \mathrm{mg} / \mathrm{g}$, respectively).

After treatment, the levels of hepatic total cholesterol and total triglyceride were significantly reduced $(\mathrm{p}<0.01)$ in the EG and DG mice when compared with those in the MG mice. The corresponding values in the EG vs the MG mice were $14.20 \pm 0.34 \mathrm{mM}$ vs $25.15 \pm 0.76 \mathrm{mg} / \mathrm{g}$; and $45.60 \pm 1.25 \mathrm{mg} / \mathrm{g}$ vs 
Table IV. The influence of electroacupuncture on hepatic total cholesterol and total triglyceride.

\begin{tabular}{lccccc}
\hline & NG $(\mathrm{n}=8)$ & MG $(\mathrm{n}=8)$ & ENG $(\mathrm{n}=9)$ & EG $(\mathrm{n}=8)$ & DG $(\mathrm{n}=8)$ \\
\hline TG (mg/g fresh liver) & $\begin{array}{c}16.37 \pm 1.12 \\
\text { aaccddee }\end{array}$ & $\begin{array}{c}58.23 \pm 3.02 \\
\text { bbccdd }\end{array}$ & $\begin{array}{c}59.07 \pm 2.95 \\
\text { bbccdd }\end{array}$ & $\begin{array}{c}45.60 \pm 1.25 \\
\text { aabbee }\end{array}$ & $\begin{array}{c}45.70 \pm 1.57 \\
\text { aabbee }\end{array}$ \\
TC (mg/g fresh liver) & $\begin{array}{c}5.41 \pm 0.40 \\
\text { aaccdd }\end{array}$ & $\begin{array}{c}25.15 \pm 0.76 \\
\text { bbccdd }\end{array}$ & $\begin{array}{c}25.23 \pm 0.58 \\
\text { bbccdd }\end{array}$ & $\begin{array}{c}14.20 \pm 0.34 \\
\text { aabbee }\end{array}$ & $14.16 \pm 0.38$ \\
aabbee
\end{tabular}

TC, total cholesterol; TG, total triglyceride. ${ }^{\text {aa }} \mathrm{vs}$ MG $\mathrm{p}<0.01 ;{ }^{\mathrm{bb}} \mathrm{vs} \mathrm{NG} \mathrm{p}<0.01 ;{ }^{\mathrm{cc}} \mathrm{vs} \mathrm{DG} \mathrm{p}<0.01 ;{ }^{\mathrm{dd}} \mathrm{vs}$ EG $\mathrm{p}<0.01 ;{ }^{\text {ee }} \mathrm{Vs}$ ENG $\mathrm{p}<0.01$.

Table V. The differentially expressed genes with known functions in MG mice compared with NG mice.

\begin{tabular}{|c|c|c|c|}
\hline Ratio & GB_accession & Description & Function \\
\hline 0.085 & NM_033580 & Protocadherin $\gamma$ subfamily B, 8 & Cell adhesion \\
\hline 0.225 & NM_023370 & Cadherin 23 (otocadherin) & Cell adhesion \\
\hline 0.225 & NM_053110 & Glycoprotein (transmembrane) nmb & Cell adhesion \\
\hline 0.24 & J04694 & Procollagen, type IV, $\alpha 1$ & Other \\
\hline 0.24 & NM_008030 & Flavin containing monooxygenase 3 & Metabolism \\
\hline 0.29 & NM_053074 & Nucleoporin 62 & Other \\
\hline 0.31 & NM_008509 & Lipoprotein lipase & Metabolism \\
\hline 0.315 & NM_033564 & Mpv17 transgene, kidney disease mutant-like & Other \\
\hline 0.32 & NM_009613 & A disintegrin and metalloprotease domain 11 & Metabolism \\
\hline 0.345 & NM_009915 & Chemokine $(\mathrm{C}-\mathrm{C})$ receptor 2 & Response to stress \\
\hline 0.35 & AF017182 & SRY-box containing gene 10 & Other \\
\hline 0.35 & NM_007935 & Enhancer of polycomb homolog 1 (Drosophila) & Other \\
\hline 0.36 & NM_007629 & Cyclin B1, related sequence 1 & Cell cycle \\
\hline 0.37 & NM_023211 & Upregulated during skeletal muscle growth 5 & Other \\
\hline 0.38 & ВC006732 & Cytochrome b-561 & Metabolism \\
\hline 0.385 & NM_033327 & Early B-cell factor associated zinc finger protein & Immunity \\
\hline 0.39 & NM_007681 & Centromere autoantigen A & Other \\
\hline 0.395 & NM_007609 & Caspase 11 & Immunity \\
\hline 0.405 & NM_011414 & Secretory leukocyte protease inhibitor & Immunity \\
\hline 0.415 & NM_019576 & Transmembrane molecule with thrombospondin module & Other \\
\hline 0.425 & NM_008933 & Protamine 2 & Other \\
\hline 0.425 & NM_010357 & Glutathione S-transferase, $\alpha 4$ & Response to stress \\
\hline 0.43 & NM_019922 & Cartilage associated protein & Other \\
\hline 0.445 & NM_013882 & G two $\mathrm{S}$ phase expressed protein 1 & Cell cycle \\
\hline 0.445 & NM_010861 & Myosin light chain, phosphorylatable, cardiac ventricles & Other \\
\hline 0.445 & NM_009994 & Cytochrome P450, 1b1, benz[a]anthracene inducible & Metabolism \\
\hline 0.445 & NM_009650 & A kinase anchor protein 3 & Other \\
\hline 0.465 & AF149291 & Transgelin 2 & Other \\
\hline 0.47 & NM_024189 & YY1 associated factor 2 & Other \\
\hline 0.485 & NM_011315 & Serum amyloid A 3 & Response to stress \\
\hline 0.49 & NM_008047 & Follistatin-like & Other \\
\hline 0.49 & NM_022881 & Regulator of G-protein signaling 18 & Signal transduction \\
\hline 0.5 & NM_008048 & Insulin-like growth factor binding protein 7 & Other \\
\hline 2.055 & NM_011387 & Solute carrier family 10 (sodium/bile acid cotransporter family), member 1 & Metabolism \\
\hline 2.055 & NM_030719 & Opposite strand transcription unit to Stage 3 & Other \\
\hline 2.07 & NM_010001 & Cytochrome P450, 2c37 & Metabolism \\
\hline 2.1 & NM_011169 & Prolactin receptor & Other \\
\hline
\end{tabular}


Table V. Continued.

\begin{tabular}{|c|c|c|c|}
\hline Ratio & GB_accession & Description & Function \\
\hline 2.15 & X98848 & 6-phosphofructo-2-kinase/fructose-2,6-biphosphatase 1 & Metabolism \\
\hline 2.18 & NM_016668 & Betaine-homocysteine methyltransferase & Other \\
\hline 2.19 & NM_011819 & Growth differentiation factor 15 & Signal transduction \\
\hline 2.24 & NM_011894 & SH3-domain binding protein 5 (BTK-associated) & Other \\
\hline 2.26 & NM_008458 & Kallikrein binding protein & Other \\
\hline 2.28 & $\mathrm{BC} 005552$ & Asparagine synthetase & Metabolism \\
\hline 2.305 & NM_008952 & Peroxisomal sarcosine oxidase & Metabolism \\
\hline 2.385 & NM_008382 & Inhibin $\beta \mathrm{E}$ & Other \\
\hline 2.48 & NM_016720 & Neuraminidase 3 & Metabolism \\
\hline 2.585 & NM_054048 & RE1-silencing transcription factor (REST) co-repressor & Signal transduction \\
\hline 2.645 & AF245444 & Glutamate receptor, ionotropic, kainate 3 & Other \\
\hline 2.695 & NM_053177 & Mucolipin 1 & Metabolism \\
\hline 2.705 & AF250912 & Solute carrier family 21 (organic anion transporter), member 6 & Metabolism \\
\hline 2.83 & NM_007606 & Carbonic anhydrase 3 & Metabolism \\
\hline 3.04 & NM_011046 & Proprotein convertase subtilisin/kexin type 3 & Metabolism \\
\hline 3.39 & AF100198 & NAD (P) dependent steroid dehydrogenase-like & Metabolism \\
\hline 3.415 & NM_007825 & Cytochrome P450, 7b1 & Metabolism \\
\hline 3.925 & NM_008648 & Major urinary protein 4 & Transport \\
\hline 3.975 & NM_013797 & Solute carrier family 21 (organic anion transporter), member 1 & Metabolism \\
\hline 4.26 & NM_019538 & Placenta specific protein 1 & Other \\
\hline 4.715 & NM_009270 & Squalene epoxidase & Metabolism \\
\hline 4.745 & M16357 & Major urinary protein 3 & Transport \\
\hline 7.08 & M16360 & Major urinary protein 5 & Transport \\
\hline 7.815 & NM_010012 & Cytochrome P450, 8b1, sterol $12 \alpha$-hydrolase & Metabolism \\
\hline 12.745 & AK017593 & Follicle stimulating hormone $\beta$ & Other \\
\hline
\end{tabular}

Differentially expressed genes with known functions in MG mice compared with NG mice. The ratio value $<0.5$ indicates the gene expression was up-regulated in the MG mice compared with NG mice; the ratio value $>2$ indicates the gene expression was down-regulated in the MG mice compared with NG mice.
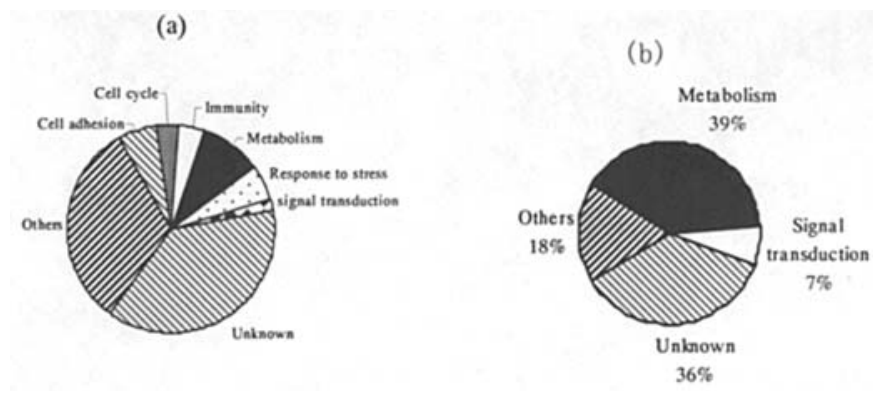

Figure 4. Distribution of the differentially expressed genes in the most representative classes in MG mice compared with NG mice. (a) induced; (b) repressed. Genes were grouped into these categories according to the Gene Ontology Consortium (http://www.geneontology. org/).

$58.23 \pm 3.02 \mathrm{mg} / \mathrm{g}$ respectively, whereas those in the DG versus the MG mice were $14.16 \pm 0.38 \mathrm{mg} / \mathrm{g}$ vs $25.15 \pm 0.76 \mathrm{mg} / \mathrm{g}$; and $45.70 \pm 1.57 \mathrm{mg} / \mathrm{g}$ vs $58.23 \pm 3.02 \mathrm{mg} / \mathrm{g}$, respectively. By contrast, these values were not significantly influenced in the ENG mice when compared with corresponding values in the
MG mice. The result of the liver lipid profile was consistent with the plasma lipid profile.

Global gene expression profiles on EA-treated livers. The effects of EA or simvastatin treatment were further evaluated by cDNA microarray analysis, where $>16,000$ genes were examined simultaneously. The global expression profiling showed distinct expression patterns in the different groups of mice. For example, many significantly expressed genes in the MG group were related to metabolism (Table V, Fig. 4); while in the EA at ST40 group (EG group) they were related to signal transduction (Table VI, Fig. 5). In the ENG mice (Table VII, Fig. 6) many of the significantly expressed genes were of unknown functions, and in the DG mice, many were related to immunity (Table VIII, Fig. 7).

Verification of EA-affected gene expression by real-time $P C R$. To confirm the microarray results, we performed realtime quantitative RT-PCR on two genes whose expression was similarly affected in both the EG and the DG mice, secretary leukocyte protease inhibitor (SLPi) and growth 
Table VI. The differentially expressed genes with known functions in EG mice compared with MG mice.

\begin{tabular}{|c|c|c|c|}
\hline Ratio & GB_accession & Definition & Function \\
\hline 0.259 & NM_033580 & Protocadherin $\gamma$ subfamily B, 8 & Cell adhesion \\
\hline 0.299 & NM_011414 & Secretory leukocyte protease inhibitor & Immunity \\
\hline 0.322 & NM_011962 & Procollagen-lysine, 2-oxoglutarate 5-dioxygenase 3 & Other \\
\hline 0.433 & NM_009906 & Ceroid-lipofuscinosis, neuronal 2 & Other \\
\hline 0.450 & NM_022882 & Lipin 2 & Other \\
\hline 0.467 & Y15910 & Diaphanous homolog 2 (Drosophila) & Other \\
\hline 0.467 & NM_009281 & Selenocysteine tRNA gene transcription activating factor & Transcription regulator \\
\hline 0.472 & NM_013619 & Olfactory receptor 67 & Other \\
\hline 0.486 & NM_010937 & Neuroblastoma ras oncogene & Signal transduction \\
\hline 2.04 & NM_021274 & Small inducible cytokine B subfamily (Cys-X-Cys), member 10 & Response to stress \\
\hline 2.06 & X67644 & Immediate early response 3 & Signal transduction \\
\hline 2.105 & NM_013639 & Peripherin 1 & Cell cycle \\
\hline 2.19 & NM_007987 & Tumor necrosis factor receptor superfamily, member 6 & Signal transduction \\
\hline 2.19 & NM_007408 & Adipose differentiation related protein & Other \\
\hline 2.5 & NM_011579 & T-cell specific GTPase & Immunity \\
\hline 3.125 & NM_009140 & Small inducible cytokine subfamily, member 2 & Response to stress \\
\hline 3.507 & M22326 & Early growth response 1 & Signal transduction \\
\hline 3.69 & NM_011819 & Growth differentiation factor 15 & Signal transduction \\
\hline 4.651 & NM_021408 & Usher syndrome 2A (autosomal recessive, mild) homolog & Other \\
\hline
\end{tabular}

Part of the differentially expressed genes with known functions in EG mice compared with MG mice. The ratio value $<0.5$ indicates the gene expression was down-regulated in the EG mice; the ratio value $>2$ indicates the gene expression was up-regulated in the EG mice compared with MG mice.

(a)

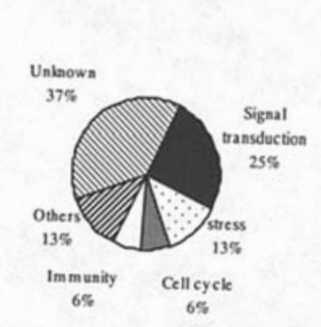

(b)

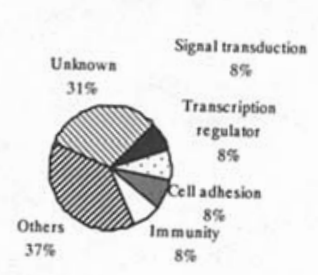

Figure 5. Distribution of the differentially expressed genes in the most representative classes in EG mice compared with MG mice. (a) induced; (b) repressed. Genes were grouped into these categories according to the Gene Ontology Consortium (http://www.geneontology.org/).

(a)

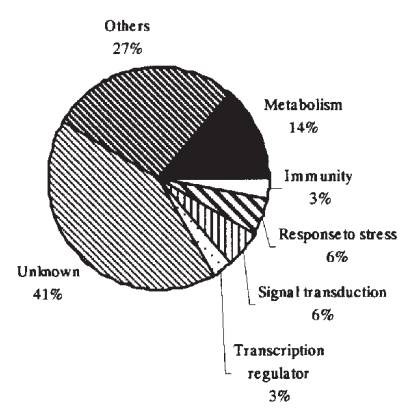

(b)

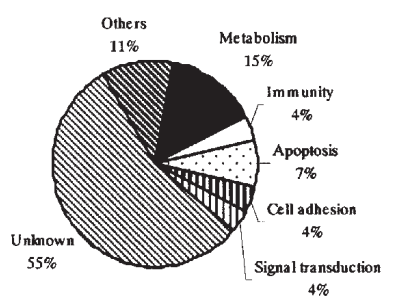

Figure 6. Distribution of the differentially expressed genes in the most representative classes in ENG mice compared with MG mice. (a) induced; (b) repressed. Genes were grouped into these categories according to the Gene Ontology Consortium (http://www.geneontology.org/).

differentiation factor 15 (Gdf15). In addition, the expression of 10 other genes involved in cholesterol metabolism in the liver was also verified in order to get insight into the molecular mechanism of the effect of EA or simvastatin on cholesterol 
Table VII. The differentially expressed genes with known functions in ENG mice compared with MG mice.

\begin{tabular}{|c|c|c|c|}
\hline Ratio & GB_accession & Definition & Function \\
\hline 0.108 & NM_033580 & Protocadherin $\gamma$ subfamily B, 8 & Cell adhesion \\
\hline 0.205 & NM_007703 & Elongation of very long chain of fatty acids (FEN1/Elo2, SUR4/Elo3, yeast)-like 3 & Metabolism \\
\hline 0.310 & NM_010811 & $\mathrm{N}$-deacetylase/N-sulfotransferase (heparan glucosaminyl) 2 & Other \\
\hline 0.366 & BC006026 & immunoglobulin joining chain & Immunity \\
\hline 0.399 & NM_011817 & Growth arrest and DNA-damage-inducible $45 \gamma$ & Apoptosis \\
\hline 0.412 & ВC005552 & Asparagine synthetase & Metabolism \\
\hline 0.452 & NM_007523 & BCL2-antagonist/killer 1 & Apoptosis \\
\hline 0.462 & AY037837 & Single-stranded DNA binding protein 2 & Other \\
\hline 0.467 & NM_009008 & RAS-related $\mathrm{C} 3$ botulinum substrate 2 & Signal transduction \\
\hline 0.473 & NM_013792 & $\alpha$-N-acetylglucosaminidase (Sanfilippo disease IIIB) & Metabolism \\
\hline 0.481 & NM_020264 & Seminal vesicle protein, secretion 7 & Other \\
\hline 0.498 & U33557 & Folylpolyglutamyl synthetase & Metabolism \\
\hline 2.04 & NM_009613 & A disintegrin and metalloprotease domain 11 & Metabolism \\
\hline 2.08 & ВC010840 & LIM and SH3 protein 1 & Other \\
\hline 2.08 & NM_019920 & Mitogen-activated protein kinase kinase 1 interacting protein 1 & Signal transduction \\
\hline 2.1 & AK002576 & Mammary tumor integration site 6 & Other \\
\hline 2.15 & NM_008212 & L-3-hydroxyacyl-Coenzyme A dehydrogenase, short chain & Metabolism \\
\hline 2.19 & NM_009474 & Urate oxidase & Metabolism \\
\hline 2.19 & ВC006852 & Wee 1 homolog (S. pombe) & Other \\
\hline 2.19 & NM_025812 & High mobility group 20A & Other \\
\hline 2.19 & NM_053082 & Transmembrane 4 superfamily member 7 & Other \\
\hline 2.19 & ВC002066 & Superoxide dismutase 1 , soluble & Response to stress \\
\hline 2.27 & AK019960 & SET translocation & Other \\
\hline 2.40 & NM_008883 & Plexin 3 & Other \\
\hline 2.46 & AF250912 & Solute carrier family 21 (organic anion transporter), member 6 & Metabolism \\
\hline 2.53 & AK019495 & DEAD/H (Asp-Glu-Ala-Asp/His) box polypeptide 10 (RNA helicase) & Other \\
\hline 2.59 & NM_021792 & Interferon-inducible GTPase & Immunity \\
\hline 3.12 & NM_011521 & Syndecan 4 & Other \\
\hline 3.22 & ВC022110 & Aminolevulinic acid synthase 1 & Metabolism \\
\hline 3.44 & NM_008287 & Heat-responsive protein 12 & Other \\
\hline 3.57 & NM_007539 & Bradykinin receptor, $\beta$ & Signal transduction \\
\hline 5.26 & M12660 & Mouse $\mathrm{CFh}$ locus, complement protein $\mathrm{H}$ gene, complete cds, clones $\mathrm{MH}(4,8)$ & Response to stress \\
\hline 5.55 & NM_016974 & D site albumin promoter binding protein & Transcription regulator \\
\hline
\end{tabular}

(a)

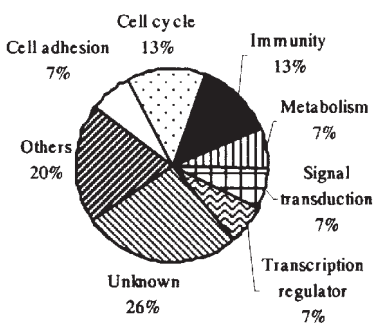

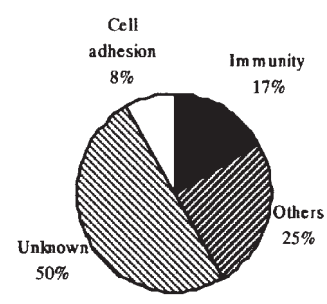

Figure 7. Distribution of the differentially expressed genes in the most representative classes in DG mice compared with MG mice. (a) induced; (b) repressed. Genes were grouped into these categories according to the Gene Ontology Consortium (http://www.geneontology.org/). 
Table VIII. The differentially expressed genes with known functions in DG mice compared with MG mice.

\begin{tabular}{|c|c|c|c|}
\hline Ratio & GB_accession & Definition & Function \\
\hline 0.085 & NM_033580 & Protocadherin gamma subfamily $\mathrm{B}, 8$ & Cell adhesion \\
\hline 0.175 & NM_011414 & Secretory leukocyte protease inhibitor & Immunity \\
\hline 0.405 & NM_023211 & Upregulated during skeletal muscle growth 5 & Others \\
\hline 0.475 & AY037837 & Single-stranded DNA binding protein 2 & Others \\
\hline 0.485 & NM_020264 & Seminal vesicle protein, secretion 7 & Others \\
\hline 0.5 & NM_033327 & Early B-cell factor associated zinc finger protein & Immunity \\
\hline 2.02 & NM_053110 & Glycoprotein (transmembrane) $\mathrm{nmb}$ & Cell adhesion \\
\hline 2.07 & NM_009507 & Von Hippel-Lindau syndrome homolog & Others \\
\hline 2.125 & NM_011284 & Replication protein A2 & Cell cycle \\
\hline 2.26 & NM_025310 & $\begin{array}{l}\text { Ectoplacental cone, invasive trophoblast giant cells, extraembryonic ectoderm and } \\
\text { chorion sequence } 3\end{array}$ & Others \\
\hline 2.4 & NM_007570 & B-cell translocation gene 2, anti-proliferative & Immunity \\
\hline 2.46 & L32973 & Thymidylate kinase family LPS-inducible member & Metabolism \\
\hline 2.475 & ВC020042 & Core promoter element binding protein & Transcription regulator \\
\hline 2.825 & NM_011579 & T-cell specific GTPase & Immunity \\
\hline 3.03 & NM_007465 & Baculoviral IAP repeat-containing 3 & Cell cycle \\
\hline 3.89 & NM_011858 & Neuregulin 1 & Others \\
\hline 6.25 & NM_011819 & Growth differentiation factor 15 & Signal transduction \\
\hline
\end{tabular}

The differentially expressed genes with known functions in DG mice compared with MG mice. The ratio value $<0.5$ indicates the gene expression was downregulated in the DG mice; the ratio value $>2$ indicates the gene expression was up-regulated in the DG mice.

Table IX. Verification of genes from microarray results by real-time RT-PCR using GAPDH as internal standard.

\begin{tabular}{|c|c|c|c|c|}
\hline & & NG vs MG & EG vs MG & DG vs MG \\
\hline Slpi & $\begin{array}{c}\text { Microarray data } \\
\text { Quantitative PCR data }\end{array}$ & $\begin{array}{l}0.40 \\
0.10\end{array}$ & $\begin{array}{l}0.29 \\
0.38\end{array}$ & $\begin{array}{l}0.17 \\
0.42\end{array}$ \\
\hline Gdf15 & $\begin{array}{c}\text { Microarray data } \\
\text { Quantitative PCR data }\end{array}$ & $\begin{array}{l}\mathrm{ND} \\
2.19\end{array}$ & $\begin{array}{l}5.0 \\
3.69\end{array}$ & $\begin{array}{l}3.8 \\
6.25\end{array}$ \\
\hline CYP7A1 & $\begin{array}{c}\text { Microarray data } \\
\text { Quantitative PCR data }\end{array}$ & $\begin{array}{l}\mathrm{ND} \\
5.87\end{array}$ & $\begin{array}{l}\mathrm{ND} \\
1.33\end{array}$ & $\begin{array}{l}\text { ND } \\
0.66\end{array}$ \\
\hline Hmgcr & $\begin{array}{c}\text { Microarray data } \\
\text { Quantitative PCR data }\end{array}$ & $\begin{array}{l}\mathrm{ND} \\
1.20\end{array}$ & $\begin{array}{l}\mathrm{ND} \\
1.26\end{array}$ & $\begin{array}{l}\text { ND } \\
0.99\end{array}$ \\
\hline FXR & $\begin{array}{c}\text { Microarray data } \\
\text { Quantitative PCR data }\end{array}$ & $\begin{array}{l}1.38 \\
1.39\end{array}$ & $\begin{array}{l}1.00 \\
0.96\end{array}$ & $\begin{array}{l}0.93 \\
0.53\end{array}$ \\
\hline $\mathrm{LXR} \alpha$ & $\begin{array}{c}\text { Microarray data } \\
\text { Quantitative PCR data }\end{array}$ & $\begin{array}{l}\text { ND } \\
0.53\end{array}$ & $\begin{array}{l}0.97 \\
0.83\end{array}$ & $\begin{array}{l}1.02 \\
0.39\end{array}$ \\
\hline Ррар $\alpha$ & $\begin{array}{c}\text { Microarray data } \\
\text { Quantitative PCR data }\end{array}$ & $\begin{array}{l}1.42 \\
1.46\end{array}$ & $\begin{array}{l}1.16 \\
1.24\end{array}$ & $\begin{array}{l}0.97 \\
1.37\end{array}$ \\
\hline LDLR & $\begin{array}{c}\text { Microarray data } \\
\text { Quantitative PCR data }\end{array}$ & $\begin{array}{l}1.915 \\
2.00\end{array}$ & $\begin{array}{l}\mathrm{ND} \\
1.08\end{array}$ & $\begin{array}{l}\text { ND } \\
0.78\end{array}$ \\
\hline NTCP & $\begin{array}{c}\text { Microarray data } \\
\text { Quantitative PCR data }\end{array}$ & $\begin{array}{l}2.055 \\
2.25\end{array}$ & $\begin{array}{l}1.23 \\
0.73\end{array}$ & $\begin{array}{l}\text { ND } \\
0.77\end{array}$ \\
\hline BSEP & $\begin{array}{c}\text { Microarray data } \\
\text { Quantitative PCR data }\end{array}$ & $\begin{array}{l}0.90 \\
1.52\end{array}$ & $\begin{array}{l}0.79 \\
1.09\end{array}$ & $\begin{array}{l}0.99 \\
1.37\end{array}$ \\
\hline OATP-1 & $\begin{array}{c}\text { Microarray data } \\
\text { Quantitative PCR data }\end{array}$ & $\begin{array}{r}8.38 \\
30.68\end{array}$ & $\begin{array}{l}1.43 \\
1.01\end{array}$ & $\begin{array}{l}\text { ND } \\
1.61\end{array}$ \\
\hline Scarb1 & $\begin{array}{c}\text { Microarray data } \\
\text { Quantitative PCR data }\end{array}$ & $\begin{array}{l}\mathrm{ND} \\
0.81\end{array}$ & $\begin{array}{l}\mathrm{ND} \\
1.01\end{array}$ & $\begin{array}{l}\text { ND } \\
1.18\end{array}$ \\
\hline
\end{tabular}

ND, not detected. 


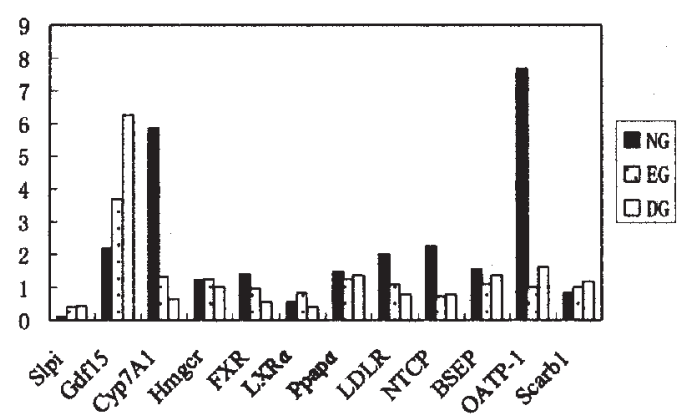

Figure 8. Quantitative RT-PCR result using GAPDH as the internal standard. Values shown represent the result of quantitative RT-PCR. The MG RNA sample was used here as the control. The EG, NG and DG RNA sample was used as the sample respectively. The GAPD gene [NM_008084 (GenBank)] was used here as a reference gene after a pilot comparison between several housekeeping genes. Note that the quantitative RT-PCR result of Oatp-1 represented in this figure is 7.67, not 30.68 which is the primitive value of the quantitative RT-PCR result (Table IX). The value was reduced 4 times so that the expression difference among other genes in one figure could be easily seen.

metabolism. The result of the quantitative PCR in the MG, NG, EG, and DG samples is shown in Table IX and Fig. 8. In short, the real-time quantitative RT-PCR results were consistent with those of the microarray analysis.

Comparison of molecular mechanisms of liver cholesterol metabolism between the EG and DG treatment. To further address possible mechanisms by which EA at ST40 exerts a hypocholesterolemic effect, we investigated the expression pattern of several key players in cholesterol metabolism, and compared it with that in the DG mice.

LXR $\alpha$ (22) encodes liver X receptor $\alpha$, a nuclear receptor that functions as a cholesterol sensor and stimulates CYP7 $\alpha 1$ expression to convert excess cholesterol to bile acids in response to high cholesterol. $\mathrm{LXR} \alpha$ is a potential therapeutic target for lowering serum cholesterol levels and preventing atherosclerosis (23). The LXR $\alpha$ mRNA levels in the MG mice were 1.88 -fold of those in the NG mice, probably resulting from the response to the high cholesterol diet. Compared with those in the MG mice, $\mathrm{LXR} \alpha \mathrm{mRNA}$ levels were 0.83 -fold and 0.39 -fold in the EG and DG mice, respectively, suggesting that EA at ST40 could maintain high LXR $\alpha$ expression, while simvastatin could not.

CYP7A1 encodes cholesterol $7 \alpha$ hydroxlase, an enzyme that catalyzes the rate-limiting steps in conversion of cholesterol to bile acids (24). The enzyme is regulated predominantly at the transcriptional level, indicating that mRNA levels are a good reflection of protein levels (24). Interestingly, whereas the expression of the CYP7A1 gene in the EG mice was upregulated 1.33-fold compared with the MG mice, it was down-regulated (0.66-fold) in the DG mice compared with the MG mice. It indicated that EA at ST40 could induce CYP7A1 gene expression but simvastatin could not.

FXR, farnesoid $\mathrm{X}$ receptor, acts as a bile acid receptor, maintaining homeostasis in response to increased bile acid levels by repressing genes involved in bile acid synthesis (25). FXR antagonists can induce bile acid synthesis and lower the plasma cholesterol (25). FXR mRNA levels were reduced $\sim 50 \%$ in the DG mice compared with the MG mice, whereas in EG they were unchanged. Thus, simvastatin suppressed the FXR gene expression while EA did not.

We also measured the expression level of one of the canalicular membrane proteins involved in hepatobiliary excretion, the bile salt export pump (BSEP; also known as sister of P-glycoprotein, Spgp). BSEP (26) is a member of the ABC transporter family and mediates ATP-dependent bile acid efflux from the canalicular membrane, which is considered the rate-determining step in bile acid secretion (27). Under the high cholesterol diet, the BSEP mRNA levels were reduced $>50 \%$ in the $\mathrm{MG}$ compared with the NG. Treatment by simvastatin elevated the expression of BSEP back to the normal level, whereas EA at ST40 had no effect on BSEP expression.

Distinct transporters on the sinusoidal membrane mediate hepatic bile acid uptake from the enterohepatic circulation by sodium-dependent and sodium-independent processes. We thus examined expression levels of two of these transporters: the sodium/taurocholate cotransporting polypeptide (28) (NTCP) and the mouse homologue of the liver-specific organic anion transporting polypeptide-1 (29) (OATP-1). The high cholesterol diet reduced expression of both genes, modestly on NTCP and dramatically on OATP-1 (2.2-fold and 30.6-fold in NG than in MG, respectively). Treatment of either EA at ST40 or simvastatin further albeit slightly reduced NTCP expression level. On the other hand, the OATP-1 expression level in the DG was elevated, 1.61-fold higher than that in the MG, whereas in the EG it was unchanged.

We also attempted to measure the expression of HMGcoA reductase (Hmgcr), the rate-limiting enzyme in synthesizing cholesterol (30). Simvastatin, an analog of the cholesterol precursor, functions by competitively inhibiting the activity of HMG-coA reductase. Given that the expression of HMG-coA reductase was suppressed by the high cholesterol diet, it was no surprise that we failed to detect this gene expression in the microarray studies. According to the result of real-time quantitative PCR, however, the expression of HMG-coA reductase was unchanged in all groups. This is consistent with the fact that the regulation of activity of HMG-coA reductase is not at the transcriptional level (25).

The low-density lipoprotein receptor (LDLR) uptakes serum cholesterol esters by a low-density lipoprotein (LDL) receptor-mediated endocytosis which is one of the major cholesterol input mechanisms in the liver (25). The LDLR gene expression decreased in the MG compared with that in the $\mathrm{NG}$, and is further reduced in the DG compared with $\mathrm{MG}$ (the DG to MG ratio by quantitative RT-PCR was 0.78 ). However, its expression did not change between the EG and MG.

The genes whose expression was unchanged after treatments of EA at ST40 or simvastatin included scavenger receptor class B1 (Scarb1) and peroxisome proliferator activated receptor $\alpha(\operatorname{PPAR} \alpha)$, as suggested by quantitative RT-PCR. Scarb1 (31) is the high-density lipoprotein receptor that is responsible for taking up high-density lipoprotein cholesterol. PPAR $\alpha$ (32) is expressed in the liver, heart, and adipose tissues, all of which have an active fatty acid $B$ oxidation pathway. The activation of PPAR $\alpha$ affects many genes in lipid metabolism. 


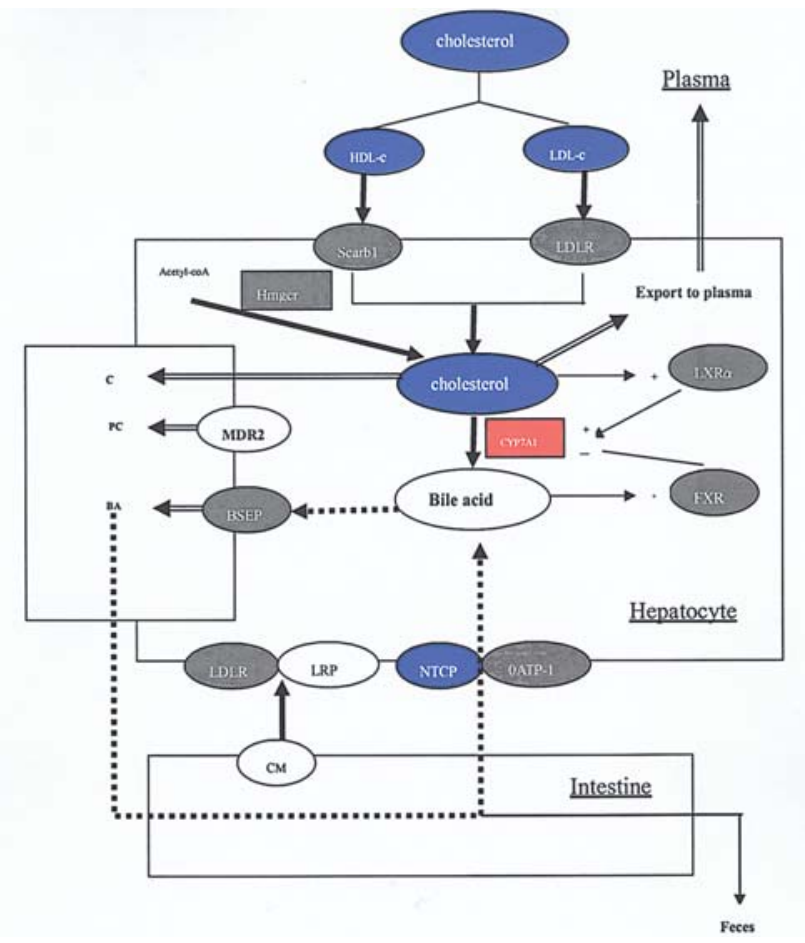

Figure 9. Summary of gene expression differences between EG and MG. Relative hepatic mRNA levels in EG compared with MG liver are indicated for genes involved in cholesterol metabolism. Red shading indicates increased mRNA expression levels in EG compared with MG for gene encoding bile acid synthetic enzyme (CYP7A1). Blue shading indicates lower levels in EG compared with MG, including plasma TC. HDL-c, LDL-c levels and mRNA levels for NTCP. mRNA levels for FXR, Hmgcr, LDLR, Scarbl, OATP-1, and BSEP did not differ between EG and MG (gray shading). Components with no shading have not been quantitated. + and - signs indicate positive and negative regulatory effects, respectively. C, cholesterol; PC, phosphatidylcholine; BA, bile acid; MDR2, multidrug-resistant protein 2. CM, chylomicron; LRP, LDL receptor-related protein; other abbreviations are as described in the text.

Two genes, secretory leukocyte protease inhibitor (SLPi) and growth differentiation factor 15 (Gdf15), were influenced to a similar extent in both EG and DG. SLPi is a serine protease inhibitor involved in antineutrophil elastase protection at inflammatory sites (33). SLPi mRNA levels were elevated in MG by more than 2-fold compared with $\mathrm{NG}$, and were reduced to normal level in DG and EG. Gdf15, one of the murine transforming growth factor $B$ superfamily members, has a regulatory role in liver injury and regeneration (34). Gdf15 mRNA levels were reduced in MG by more than 2-fold compared with NG, but returned to normal in DG and EG.

The gene expression differences between EG and DG for these genes are summarized in Figs. 9 and 10, respectively. Taken together, although EA at ST40 and simvastatin both reduced plasma and liver cholesterol levels to a similar extent, our genome-wide expression profile studies suggest that the molecular mechanisms by which the two treatments exert hypocholesterolemic effects are quite different, at least in the liver. The lower cholesterol levels in EG mice are associated with higher expression levels of LXR $\alpha$ and genes encoding bile acid synthetic enzymes such as CYP7A1, whereas in the DG mice they are associated with lower FXR mRNA levels and higher expression levels of genes encoding membrane-associated bile acid transporters (such as liver-

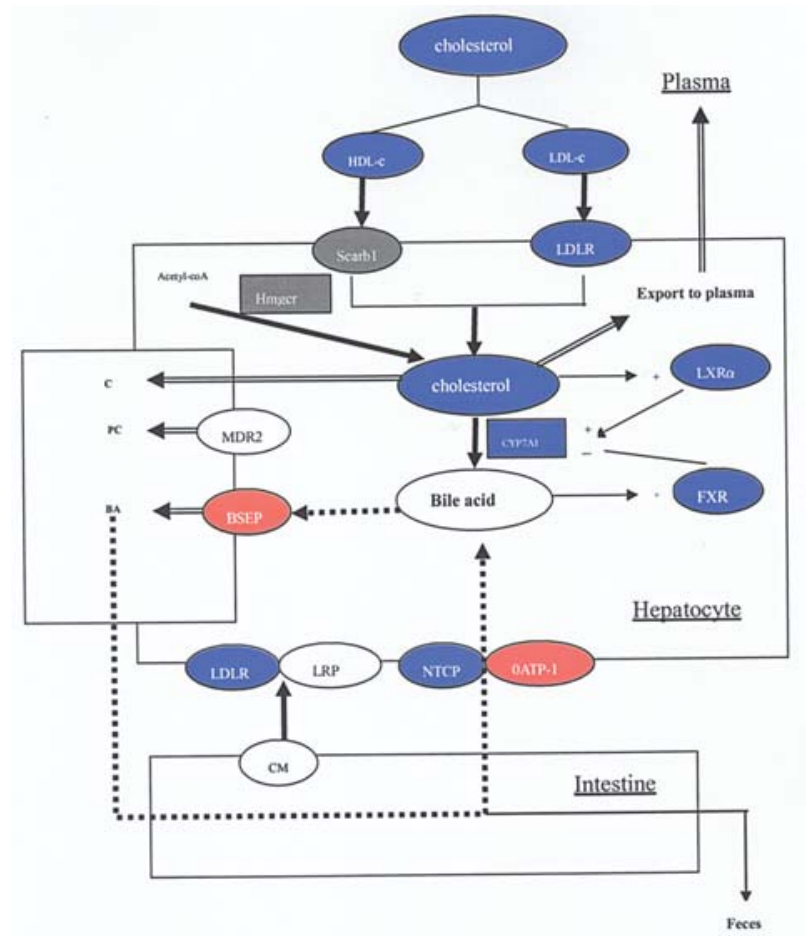

Figure 10. Summary of gene expression differences between DG and MG. Relative hepatic mRNA levels in DG compared with MG liver are indicated for genes involved in cholesterol metabolism. Red shading indicates increased mRNA expression levels in DG compared with MG for proteins involved in bile acid transporters on the sinusoidal membrane (liver specific OATP-1) and bile translocators on the canalicular membrane (BSEP). Blue shading indicates lower levels in DG and includes plasma lipoprotein cholesterol levels, mRNA levels for FXR, CYP7H1, LDLR, and bile acid transporters on the sinusoidal membrane (NTCP). mRNA levels for Hmgcr and Scarbl did not differ between DG and MG (gray shading). Components with no shading have not been quantitated. + and - signs indicate positive and negative regulatory effects, respectively. C, cholesterol; PC, phosphatidylcholine; BA, bile acid; MDR2, multidrug-resistant protein 2; other abbreviations are as described in the text.

specific OATP and BSEP). Interestingly, EA at ST40 and simvastatin treatment had similar effects on the expression of SLPi and Gdf15, and may therefore exert hypocholesterolemic effects by both suppressing the inflammatory reaction and inducing liver cell regeneration.

The gene expression profile analysis presented in this study provides valuable clues for identifying the key regulators involved in the cholesterol mechanism in the liver. However, it does not directly address the question why the plasma cholesterol was reduced after EA at ST40 or simvastatin treatment. To this end, the bile acid levels in plasma and in feces for the different groups of mice should be investigated to compare the direct effect of EA at ST40 or simvastastin treatment.

It is also worth noting that the present study did not test how long the hypocholesterolemic effect lasted after administration of EA at ST40. Experiments are underway to compare the differences in transient or persistent effects between EA at ST40 and simvastatin and the switching to a normal diet after establishment of hypercholesterolemia.

In conclusion, in this study, we found that EA at ST40 could reduce plasma total cholesterol in hypercholesterolmic mice to levels similar to that induced by simvastastin, one 
of the best known cholesterol-lowering drugs. Similar EA stimulation at the non-acupoint location failed to produce such an effect in mice with hypercholesterolemia. Therefore, the hypocholesterolemic effect is specific to EA at ST40 and is not due to general electrical stimulation of muscles. Importantly, our comprehensive gene expression profile analysis suggested that, despite its similar effects compared to those of simvastastin, EA at ST40 lowered cholesterol via different molecular mechanisms. A few of the genes listed in Tables VI, VII are thought to be involved in the pathways affected by EA. Moreover, most of the genes identified by the microarray experiment have not been previously linked to cholesterol metabolism. Although the potential causal role of individual genes remains to be established, the differentially regulated genes identified by the present study can provide more clues as to how EA at ST40 induces hypocholesterolemic effects.

\section{References}

1. Pearson TA: The epidemiologic basis for population-wide cholesterol reduction in the primary prevention of coronary artery disease. Am J Cardiol 94: 4F-8F, 2004.

2. Clark LT: Treating dyslipidemia with statins: the risk-benefit profile. Am Heart J 145: 387-396, 2003.

3. Scott CL: Diagnosis, prevention, and intervention for the metabolic syndrome. Am J Cardiol 92: 352-421, 2003.

4. Normile D: The new face of Traditional Chinese Medicine. Science 299: 188-190, 2003.

5. Li Y: The review on the acupuncture treatment of hyperlipidemia. J Sichuan Tradit Chin Med 20: 23-25, 2002.

6. Liu Z: Effects of acupuncture on lipid, TXB2, 6-keto-PGF, alpha in simple obese patients complicated with hyperlipidemia. Zhen Ci Yan Jiu 21: 17-21, 1996.

7. Cabioglu MT and Ergene N: Electroacupuncture therapy for weight loss reduces serum total cholesterol, triglycerides, and LDL cholesterol levels in obese women. Am J Chin Med 33: 525-533, 2005.

8. Liu Z, Sun F, Li J, Shi X, Hu L, Wang Y and Qian Z: Prophylactic and therapeutic effects of acupuncture on simple obesity complicated by cardiovascular diseases. J Tradit Chin Med 12: 21-29, 1992.

9. Wang YT and An H: The acupuncture at Fenglong acupoint for treatment of 49 cases of hypercholesterolemia. Chin Acupunct and Moxibust 3: 21-23, 1990.

10. Li C, Cheng X, Li C, Cui M and Sun Z: Regulative effects of acupuncture at Fenglong acupoint on the blood lipids of normal rats and those with hyperlipemia. Chin J Clinic Rehabilitat 9: 86-87, 2005.

11. Xie J, Li X, Zhang L and Cheng K: Experimental study on effects of puncturing different points on blood lipid in rats with hyperlipemia. J Beijing Univ TCM 26: 80-83, 2003.

12. Yu J, Yu T and Han J: Aging-related changes in the transcriptional profile of cerebrum in senescence-accelerated mouse (SAMP10) is remarkably retarded by acupuncture. Acupunct Electrother Res 30: 27-42, 2005.

13. Guo JC, Gao HM, Chen J, Zhao P, Cao XD, Li Y and Cheng JS: Modulation of the gene expression in the protective effects of electroacupuncture against cerebral ischemia: a cDNA microarray study. Acupunct Electrother Res 29: 173-186, 2004.
14. Deng CL and Ying KJ: Experimental Acupuncture. Beijing People's Med. Publ. House, Beijing, pp148, 1998.

15. Folch J, Lees M and Sloane-Stanley GH: A simple method for the isolation and purification of total lipids from animal tissues. J Biol Chem 226: 497-509, 1957.

16. Smith L, Underhill P, Pritchard C, et al: Single primer amplification (SPA) of cDNA for microarray expression analysis. Nucleic Acids Res 31: E9, 2003.

17. Dixon AK, Richardson PJ, Lee K, et al: Expression profiling of single cells using $3^{\prime}$ prime end amplification (TPEA) PCR. Nucleic Acids Res 26: 4426-4431, 1998.

18. Yang YH, Dudoit S, Luu P, et al: Normalization for cDNA microarray data: a robust composite method addressing single and multiple slide systematic variation. Nucleic Acids Res 30: E15, 2002

19. Pfaffl MW: A new mathematical model for relative quantification in real-time RT-PCR. Nucleic Acids Res 29: E45, 2001.

20. Tichopad A, Dilger M, Schwarz G, et al: Standardized determination of real-time PCR efficiency from a single reaction set-up. Nucleic Acids Res 31: E122, 2003.

21. Xu SY, Bian RL and Chen X: Methodology of Pharmacological Experiments. 3rd edition. Beijing People's Med. Publ. House, Beijing, pp1202-1208, 2002.

22. Russell DW: Nuclear orphan receptors control cholesterol catabolism. Cell 97: 539-542, 1999.

23. Repa JJ, Turley SD, Lobaccaro JA, Medina J, Li L, Lustig K, Shan B, Heyman RA, Dietschy JM and Mangelsdorf DJ: Regulation of absorption and $\mathrm{ABC} 1$-mediated efflux of cholesterol by RXR heterodimers. Science 289: 1524-1529, 2000.

24. Vlahcevic ZR, Jaraith SK, Heuman DM, et al: Transcriptional regulation of hepatic sterol 27 -hydroxylase by bile acids. Am J Physiol 270: G646-G652, 1996.

25. Chiang JYL: Bile acid regulation of gene expression: roles of nuclear hormone receptors. Endocr Rev 23: 443-463, 2002.

26. Schriml LM and Dean M: Identification of 18 mouse ABC genes and characterization of the ABC superfamily in Mus musculus. Genomics 64: 24-31, 2000.

27. Gerloff T, Stieger B, Hagenbuch B, et al: The sister of Pglycoprotein represents the canalicular bile salt export pump of mammalian liver. J Biol Chem 273: 10046-10050, 1998.

28. Wolters H, Elzinga BM, Baller JF, et al: Effects of bile salt flux variations on the expression of hepatic bile salt transporters in vivo in mice. J Hepatol 37: 556-563, 2002.

29. Hagenbuch B, Adler ID and Schmid TE: Molecular cloning and functional characterization of the mouse organic-aniontransporting polypeptide 1 (Oatp1) and mapping of the gene to chromosome X. Biochem J 345: 115-120, 2002.

30. Helmberg A, Fassler R, Geley S, et al: Glucocorticoid-regulated gene expression in the immune system. Analysis of glucocorticoidregulated transcripts from the mouse macrophage-like cell line P388D1. J Immunol 145: 4332-4337, 1990.

31. Connelly MA, De La Llera-Moya M, Peng Y, et al: Separation of lipid transport functions by mutations in the extracellular domain of scavenger receptor class B, type I. J Biol Chem 278: 25773-25782, 2003

32. Devoogdt N, Hassanzadeh Ghassabeh G, Zhang J, et al: Secretory leukocyte protease inhibitor promotes the tumorigenic and metastatic potential of cancer cells. Proc Natl Acad Sci USA 100: 5778-5782, 2003.

33. Fu J, Gaetani S, Oveisi F, et al: Oleylethanolamide regulates feeding and body weight through activation of the nuclear receptor PPAR-alpha. Nature 425: 90-93, 2003.

34. Hsiao EC, Koniaris LG, Zimmers-Koniaris T, et al: Characterization of growth-differentiation factor 15 , a transforming growth factor beta superfamily member induced following liver injury. Mol Cell Biol 20: 3742-3751, 2000. 